\title{
Hubungan Drug Related Problems (DRPs) Obat Antidiabetika terhadap Ketercapaian Kendali Glikemik pada Pasien Rawat Inap Diabetes Melitus Tipe 2 dengan Komplikasi Nyeri Neuropati
}

\section{The Relationship Between Drug Related Problems of Antidiabetic Medication with Glicemic Control of Hospitalized Type 2 Diabetes Melitus with Neuropatic Pain Patients}

\author{
Anggraini Citra Ryshang Bathari ${ }^{1,2}$, Fita Rahmawati ${ }^{3 *}$, Ika Puspita Sari ${ }^{3}$ \\ 1. Magister Farmasi Klinik, Fakultas Farmasi, Universitas Gadjah Mada, Yogyakarta, Indonesia \\ 2. Instalasi Farmasi dan Sterilisasi, Rumah Sakit Akademik Universitas Gadjah Mada, Yogyakarta, Indonesia \\ 3. Departemen Farmakologi dan Farmasi Klinik, Fakultas Farmasi, Universitas Gadjah Mada, Yogyakarta, Indonesia \\ Submitted: 14-07-2020 Revised: 29-11-2020 Accepted: 29-12-2020
}

Korespondensi : Fita Rahmawati : Email : malihahanun@yahoo.com

\begin{abstract}
ABSTRAK
Drug Related Problems (DRPs) yang berkaitan dengan obat-obat antidiabetika sering terjadi pada pasien rawat inap Diabetes Melitus (DM) karena adanya komorbid, komplikasi, dan polifarmasi. Nyeri neuropati merupakan salah satu komplikasi DM dengan prevalensi kejadian diabetik neuropati meliputi $50 \%$ dari penyandang DM. Adanya DRPs dapat menyebabkan tidak tercapainya luaran terapi pasien. Penelitian ini bertujuan meneliti hubungan antara DRPS obat antidiabetika terhadap kendali glikemik pada pasien rawat inap DM tipe 2 dengan komplikasi nyeri neuropati. Penelitian ini menggunakan rancangan cohort retrospektif yang dilakukan di Rumah Sakit Akademik Universitas Gadjah Mada. Penelitian ini melibatkan 50 pasien yang terbagi dalam kelompok yang mengalami DRPs sebanyak 36 pasien dan kelompok non DRPS sebanyak 14 pasien. Data diambil dari rekam medis pasien rawat inap periode tahun 2018-2019 yang memenuhi kriteria inklusi. DRPs yang dinilai meliputi pemilihan obat kurang tepat, perlu tambahan terapi, dan perlu penambahan dosis. Luaran terapi yang dinilai adalah tercapainya kendali glikemik sesuai kriteria American Diabetic Association 2019. Analisis hubungan DRPs obat antidiabetika terhadap ketercapaian kendali glikemik menggunakan Chi-square test dengan taraf kepercayaan $95 \%$ dan kemaknaan $\mathrm{p}<0,05$. Dari hasil penelitian diidentifikasi DRPs sebanyak 38 kejadian. Kategori kejadian drug related problems terdiri dari butuh tambahan terapi obat sebesar $26,3 \%$, obat salah sebesar $55,2 \%$, dosis terlalu rendah sebesar $18,4 \%$. Terdapat hubungan antara drug related problems obat antidiabetika terhadap ketercapaian kendali glikemik pada pasien diabetes melitus tipe 2 dengan komplikasi nyeri neuropati rawat inap $(p=0,005)$. Identifikasi DRPs sangat diperlukan untuk mencegah timbulnya efek negatif luaran terapi pasien.
\end{abstract}

Kata kunci: Diabetes melitus type 2; Drug related Problems; target glikemik; komplikasi neuropati

\begin{abstract}
Drug Related Problems (DRPs) associated with Type-2 Diabetes Melitus is commonly caused by multi drug prescription since Type-2 Diabetes Mellitus has comorbid dan complication diseases. Neuropathic pain has $50 \%$ prevalence of Type- 2 diabetes Mellitus Complication. DRPs can cause can cause inadequate therapy that might be the risk factor leads to neuropathic pain. This study was aimed to investigate the association between drug related problems of antidiabetic medication with glicemic control of hospitalized type 2 diabetes melitus with neuropathic pain patients. Cohort-study is used in this study. 50 patients were conducted in this study that underwent Hospital treatment at Rumah Sakit Akademik Universitas Gadjah Mada during the periods of 2018-2019. This study involved 50 patients who were divided into groups that experienced DRPs by 36 patients and non DRPs by 14 patients. All of the 50 has meet the inclusions criterias. Statistical analysis was using Chi-square test $95 \%$ confidence interval ( $p$ $<0.05)$. A number of 38 DRPs have found consists of $26,3 \%$ need more therapy, $55,2 \%$ with wrong drug therapy, $18,4 \%$ inadequate dosing. There was an association between DRPs of antidiabetics regiments and glycemic target on Type-2 Diabetes Mellitus patients with neuropathic pain complication $(p=0,005)$. Identification of DRPs is needed to prevent the negative effect of patient therapy outcomes.

Keywords: Drug Related Problems; glycemic target; Type-2 Diabetic mellitus
\end{abstract}

JMPF Vol 10(4), 2020 | DOI : 10.22146/jmpf.57829 


\section{PENDAHULUAN}

Diabetes telah menjadi permasalahan global terbesar di abad $21^{1}$ serta menjadi ancaman serius di dunia kesehatan. International Diabetes Federation (IDF) Atlas 2015 memperkirakan jumlah penderita diabetes pada tahun 2040 sebanyak 642 juta jiwa. Indonesia menduduki peringkat keenam dunia sebagai negara penyandang diabetes ${ }^{2}$. Riskesdas melaporkan terjadinya peningkatan prevalensi diabetes yang signifikan yaitu $6.9 \%$ di tahun 2016 menjadi 8.5\% pada tahun 2018 sehingga estimasi penderita diabetes di Indonesia adalah 16 juta orang. Laporan Surveilans Terpadu Penyakit (STP) Daerah Istimewa Yogyakarta tahun 2017 menunjukkan bahwa diabetes melitus merupakan penyakit tidak menular terbanyak keempat dengan jumlah 8.321 kasus $^{3}$.

Pencegahan terhadap terjadinya komplikasi diabetik neuropati difokuskan pada pengendalian kadar glukosa darah dan modifikasi gaya hidup. Pengendalian kadar glukosa darah dapat mengurangi resiko terjadinya komplikasi distal symmetric polyneuropathy (DSPN) sebesar $78 \%$ pada pasien DM type 1 dan $5 \%$ - 9\% pada pasien DM type 24. Penelitian Action to Control Cardiovascular Risk (ACCORD) tahun 2010 menyebutkan bahwa penurunan resiko komplikasi DSPN perlahan namun signifikan pada pasien DM type 2 yang melakukan pengendalian glikemik dan diikuti selama 5 tahun 5 . Kondisi hiperglikemia dikaitkan dengan kejadian komplikasi mikrovaskular dan makrovaskular sehingga diperlukan penanganan yang tepat ${ }^{6}$.

Salah satu bentuk manajemen DM adalah intervensi farmakologis untuk mencapai target luaran terapi yang diharapkan. Seringkali pasien DM mengalami penyulit atau komorbid sehingga beresiko mengalami drug related problems (DRPs). DRPS didefinisikan sebagai suatu kejadian permasalahan pengobatan baik aktual maupun potensial yang dapat berpengaruh terhadap luaran terapi yang akan dicapai pasien ${ }^{7}$. Sebuah penelitian yang dilakukan untuk mengidentifikasi DRPS yang muncul pada pasien DM type 2 dengan komplikasi dislipidemia memberikan hasil 406 DRPS berhasil diidentifikasi dan 91,8\% dari total pasien $(n=191)$ setidaknya mengalami satu kejadian $D R P S$ dengan rerata $1,94 \pm 1,1$ masalah tiap pasien ${ }^{8}$. Penelitian lain melakukan identifikasi $D R P S$ pada pasien DM type 2 dengan hipertensi, memberikan hasil 387 DRPs teridentifikasi dengan 90,5\% dari total pasien $(n=200)$ mengalami setidaknya satu $D R P S$ dengan rerata $1,9 \pm 1,2$ masalah tiap pasien ${ }^{9}$ Studi terdahulu telah menghubungkan antara DRPs dengan kadar glukosa darah 10 , tetapi sejauh ini belum ditemukan adanya penelitian yang menghubungkan kejadian DRPs dengan ketercapaian kendali glikemik pada pasien DM tipe 2 dengan komplikasi nyeri neuropati.

Penelitian ini bertujuan untuk mengevaluasi hubungan antara $D R P S$ obat antidiabetika terhadap kendali glikemik pada pasien rawat inap DM tipe 2 dengan komplikasi nyeri neuropati. Apoteker diharapkan dapat melakukan identifikasi dan melakukan pencegahan terhadap kejadian DRPs agar tercapai hasil terapi yang terbaik bagi pasien.

\section{METODE}

Penelitian ini menggunakan desain cohort retrospektif. Penelitian ini telah memperoleh persetujuan ethical clearance dari komite etik Fakultas Kedokteran, Kesehatan Masyarakat, dan Keperawatan Universitas Gadjah Mada No. KE/FK/0118/EC/2020.

Pengumpulan subyek dilakukan dengan menggunakan data retrospektif rekam medis pasien rawat inap periode 2018-2019. Pengumpulan sampel dilakukan dengan menggunakan teknik purposive sampling terhadap pasien DM tipe 2 rawat inap di bangsal Penyakit Dalam RSA UGM. Subyek dari penelitian ini adalah pasien rawat inap dengan diagnosa DM tipe 2 dengan komplikasi nyeri neuropati yang menjalani rawat inap tahun 2018-2019 di RSA UGM sesuai kriteria inklusi. Kriteria inklusi pada penelitian ini adalah pasien dewasa $(>18$ tahun) menjalani rawat inap di bangsal 
Penyakit Dalam RSA UGM dengan diagnosa DM tipe 2 disertai nyeri neuropati, mendapatkan terapi antidiabetika baik oral maupun injeksi, dan bukan pasien kritis (ICU). Kriteria eksklusi dalam penelitian ini adalah pasien yang mengalami sepsis atau infeksi yang didapat di rumah sakit selama masa perawatan dan pasien pulang paksa. Subyek penelitian terbagi dalam dua kelompok, yaitu kelompok pasien dengan kejadian DRPs antidiabetika dan kelompok pasien yang tidak mengalami kejadian DRPs dengan jumlah masing-masing 36 dan 14 pasien.

Penentuan rumus besar sampel dilakukan dengan menggunakan rumus besar sampel:

$$
n_{1}=n_{2}=\frac{\left(Z a \sqrt{2 P Q}+Z \beta \sqrt{P_{1} Q_{1}+P_{2} Q_{2}}\right)^{2}}{\left(P_{1}-P_{2}\right)^{2}}
$$

dengan nilai $P_{1}$ (proporsi kelompok terpapar DRPs hasil studi pendahuluan sebesar 0,64$)$ dan $Z_{\frac{a}{2}}$ serta $Z_{\beta}$ yang ditetapkan masing-masing 1,64 dan 0,842; maka jumlah minimal sampel yang diperlukan pada masing-masing kelompok adalah 29. Pada penelitian ini jumlah sampel sebanyak 50 sampel dengan kekuatan penelitian sebesar $90 \%$

DRPs kategori potensial dan aktual diidentifikasi pada penelitian ini. Kategori $D R P S$ meliputi butuh tambahan terapi obat yang didefinisikan jika dalam penelitian ini terdapat suatu kondisi klinis dan hasil pemeriksaan laboratorium yang menunjukkan bahwa pasien membutuhkan tambahan terapi obat untuk memperbaiki kondisinya namun pasien belum mendapatkan terapi tersebut selama pasien menjalani rawat inap, kategori DRPs obat salah didefinisikan bila obat yang diberikan untuk pasien merupakan obat yang efektif tetapi bukan yang paling aman, dan kategori DRPs dosis terlalu rendah.

Pengukuran luaran terapi dilihat dari pemeriksaan kadar glukosa sewaktu (GDS) dan atau glukosa puasa (GDP) yang hasilnya dinilai berdasarkan target kendali glukosa darah berdasarkan American Diabetes
Association 2019. Evaluasi GDS dan atau GDP saat pasien pertama kali masuk untuk dirawat inap akan dicatat sebagai data awal dan akan dilakukan pengukuran ulang terhadap GDS dan atau GDP sebelum pasien pulang untuk mengevaluasi ketercapaian kendali glikemik. Luaran terapi dikelompokkan menjadi tercapai dan tidak tercapai. Kriteria tercapai bila hasil pemeriksaan GDS $<200 \mathrm{mg} / \mathrm{dL}$ dan atau GDP $<130 \mathrm{mg} / \mathrm{dL}$. Kriteria tidak tercapai bila hasil pemeriksaan GDS $>200 \mathrm{mg} / \mathrm{dL}$ dan atau GDP > $130 \mathrm{mg} / \mathrm{dL}$.

Hubungan DRPS terhadap ketercapaian kendali glikemik dianalisis menggunakan $\mathrm{Chi}$ square test. Nilai $\mathrm{p}<0,05$ menunjukkan terdapat hubungan antara DRPs dengan luaran klinis ketercapaian kendali glikemik.

\section{HASIL DAN PEMBAHASAN}

Karakteristik demografi pasien pada penelitian ini meliputi distribusi pasien berdasarkan jenis kelamin, usia, dan lama rawat inap. Distribusi karakteristik demografi pasien tersaji dalam tabel I.

Tujuan penatalaksanaan diabetes melitus secara umum adalah meningkatkan kualitas hidup penyandang diabetes yang meliputi menghilangkan keluhan DM, mengurangi komplikasi akut, mencegah dan menghambat progresivitas penyulit mkiroangiopati dan makroangiopati, serta turunnya morbiditas dan mortalitas DM. Untuk mencapai tujuan tersebut perlu dilakukan pengendalian glukosa darah, tekanan darah, berat badan, dan profil lipid, melalui pengelolaan pasien secara komprehensif ${ }^{11}$.

Obat antidiabetika yang digunakan di Rumah Sakit Akademik UGM meliputi dua jenis sediaan yaitu antidiabetika oral dan injeksi (Tabel II). Obat ini dapat digunakan secara tunggal maupun kombinasi tergantung pada respon klinis pasien dan hasil dari pemeriksaan glukosa darah.

Upaya pencegahan terhadap terjadinya diabetik neuropati dilakukan melalui pengendalian glukosa dan modifikasi gaya hidup. Optimalisasi kendali glukosa dapat mencegah atau memperlambat progresifitas 
Tabel I. Karakteristik Demografi Pasien DM Tipe 2 Dengan Kompikasi Nyeri Neuropati Rawat Inap

\begin{tabular}{lccc}
\hline Karakteristik Demografi & $\begin{array}{c}\text { Jumlah Pasien } \\
\text { kelompok DRP } \\
\mathbf{( N = 3 6 )}\end{array}$ & $\begin{array}{c}\text { Jumlah Pasien } \\
\text { kelompok non DRP } \\
\mathbf{( N = 1 4 )}\end{array}$ & $\begin{array}{c}\text { Jumlah Pasien } \\
\mathbf{( N = 5 0 )}\end{array}$ \\
\hline $\begin{array}{l}\text { Jenis kelamin } \\
\text { Laki-laki }\end{array}$ & $17(47,3 \%)$ & $5(35,7 \%)$ & $23(46 \%)$ \\
$\quad \begin{array}{l}\text { Perempuan } \\
\text { Usia }\end{array}$ & $19(52,7 \%)$ & $9(64,3 \%)$ & $27(54 \%)$ \\
20-34 tahun & $1(2,8 \%)$ & $0(0 \%)$ & $1(2 \%)$ \\
35-49 tahun & $7(19,4 \%)$ & $3(21,4 \%)$ & $9(18 \%)$ \\
$50-64$ tahun & $23(63,9 \%)$ & $9(64,3 \%)$ & $32(64 \%)$ \\
$\geq 65$ tahun & $5(13,9 \%)$ & $2(14,3 \%)$ & $8(16 \%)$ \\
Durasi menderita DM & & & \\
$<5$ tahun & $17(47,2 \%)$ & $6(42,8 \%)$ & $19(38 \%)$ \\
$5-10$ tahun & $17(47,2 \%)$ & $6(42,8)$ & $27(54 \%)$ \\
$>10$ tahun & $2(5,6 \%)$ & $2(14,3)$ & $4(8 \%)$ \\
\hline
\end{tabular}

Tabel II. Pola Peresepan Obat Antidiabetika Pada Pasien DM tipe 2 dengan Komplikasi Nyeri Neuropati Rawat Inap di Rumah Sakit Akademik UGM

\begin{tabular}{llcc}
\hline Pola Peresepan & Golongan Obat Antidiabetika & $\begin{array}{c}\text { Jumlah } \\
\text { pasien }\end{array}$ & $\begin{array}{c}\text { Persentase } \\
\text { (\%) }\end{array}$ \\
\hline Tunggal & Insulin rapid acting & 18 & 36 \\
& Insulin long acting & 5 & 10 \\
& Biguanide & 6 & 12 \\
& Thiazolidinedione & 4 & 8 \\
Kombinasi 2 obat & Biguanide + thiazolidinedione & 4 & 8 \\
& Human premixed insulin & 5 & 10 \\
& Insulin rapid acting + biguanide & 4 & 8 \\
& Insulin rapid acting +long acting & 1 & 2 \\
Kombinasi 3 obat & Sulfonilurea + biguanide & 1 & 2 \\
& Acarbose + biguanide + thiazolidinedione & 1 & 2 \\
& Insulin rapid acting + biguanide & 1 & 2 \\
Total & +thiazolidinedione & & $\mathbf{5 0}$ \\
\hline
\end{tabular}

komplikasi distal simetrik polineuropati ${ }^{4}$. Tabel II menunjukkan penggunaan antidiabetika tunggal paling banyak adalah insulin rapid acting sebesar $36 \%$. Hal tersebut sesuai dengan penelitian sebelumnya yang menyebutkan penggunaan insulin rapid acting subkutan sebelum makan frekuensi 4 - 6 jam atau jika pasien menerima nutrisi enteral maupun parenteral diindikasikan untuk koreksi hiperglikemia ${ }^{12}$. Kondisi hiperglikemia pada pasien DM tipe 2 yang dirawat inap adalah ketika glukosa darah $>140$ $\mathrm{mg} / \mathrm{dL}$. Terapi insulin harus segera diberikan pada kondisi hiperglikemia persisten (glukosa darah $\geq 180 \mathrm{mg} / \mathrm{dL}$ ). Target terapi yang direkomendasikan adalah kadar gula darah antara 140 - $180 \mathrm{mg} / \mathrm{dL}$ untuk pasien critical maupun non critical 29

Pasien DM tipe 2 dengan komplikasi nyeri neuropati di RSA UGM sebagian besar masuk rumah sakit melalui instalasi gawat darurat dengan keluhan lemas, nyeri pada 
kedua tungkai, dan seringkali dalam keadaan hiperglikemia. Pada kondisi yang memerlukan regulasi glukosa darah yang relatif cepat dan tepat, insulin merupakan pilihan terbaik karena kerjanya cepat dan dosisnya dapat disesuaikan dengan hasil kadar glukosa darah. Prinsip terapi insulin dimulai dari dosis kecil yang kemudian dinaikkan secara bertahap, untuk mencegah hipoglikemia dan mungkin dapat memerlukan terapi kombinasi oral dan insulin atau insulin saja ${ }^{11}$.

Kombinasi dua obat yang banyak digunakan pada penelitian ini adalah human premixed sebesar $16,94 \%$. Insulin premixed merupakan campuran antara short-acting insulin dengan intermediate-acting insulin dalam kombinasi dosis tetap 30/70 atau 50/50. Keuntungan penggunaan human premixed insulin ini adalah dosis yang akurat, efikasi, dan kenyamanan dari pasien karena dapat meningkatkan kepatuhan penggunaan insulin dan dapat digunakan untuk pengendalian glukosa jangka panjang ${ }^{13}$. Namun demikian pada penelitian ini belum semua pasien dapat terkendali kadar glukosa dengan penggunaan insulin premixed. Hal ini dapat disebabkan karena dosis yang tidak adekuat sehingga dibutuhkan penambahan dosis.

Banyak pasien DM tipe 2 dewasa mendapatkan lebih dari 1 golongan obat antidiabetika untuk mencapai kendali glukosa yang adekuat. Kendali glukosa dapat mengurangi resiko mikrovaskular seperti neuropati dan retinopati. Kombinasi dua antidiabetika oral yang paling banyak pada penelitian ini adalah biguanide (metformin) dan thiazolidinedione (pioglitazone). Metformin merupakan first line pengobatan DM tipe 2, obat ini memiliki efikasi yang baik, aman, dan murah. Metformin diberikan pertama kali saat pasien terdiagnosa DM tipe 2 kecuali bila terdapat kontraindikasi. Pada kebanyakan kasus, penggunaan metformin dikombinasikan dengan modifikasi gaya hidup. Pada pasien yang tidak dapat mencapai target A1C yang telah ditentukan selama 3 bulan dan pasien tidak memiliki penyakit penyerta ASCVD atau CKD, dipertimbangkan penggunaan kombinasi metformin dengan enam obat antidiabetik yaitu sulfonilurea, thiazolidinedione, dipeptidyl peptidase 4 (DPP-4) inhibitor, SGLT2 inhibitor, GLP-1 reseptor agonis, atau insulin basal. Pemilihan obat ini harus berdasarkan efek spesifik obat dan kondisi pasien ${ }^{29}$.

Thiazolidinedione merupakan agonis PPAR-y. Obat ini meningkatkan sensitivitas insulin dalam jaringan otot, hati, dan lemak secara tidak langsung ${ }^{30}$. Studi PROspective pioglitAzone Clinical Trial In macroVascular Events (Proactive Study) menyatakan pioglitazone mengurangi mortalitas dari non fatal infark miokard dan stroke infark pada pasien DM tipe 2 yang beresiko tinggi terhadap penyakit makrovaskular ${ }^{14}$. Penelitian cohort Korean NHIS claim database yang mengikutsertakan 349.476 pasien DM tipe 2 menyebutkan penggunaan kombinasi metformin dan pioglitazone dihubungkan dengan penurunan total kejadian CVD, resiko stroke iskemik, dan peningkatan resiko gagal jantung dibandingkan penggunaan kombinasi DPP4i dan metformin ${ }^{15}$.

\section{Identifikasi Drug Related Problems}

Pada penelitian ini identifikasi dan penilaian terhadap terjadinya kejadian drug related problems dilakukan dengan menilai efektifitas obat antidiabetika dalam menurunkan glukosa darah pasien sesuai dengan sasaran glikemik sesuai rekomendasi dari American Diabetes Association (2019) dan rekomendasi dokter penanggung jawab pasien. Hasil penelitian menunjukkan dari total 50 pasien ditemukan 38 kejadian DRPs. Tabel III menunjukkan jenis DRPs yang teridentifikasi.

\section{Butuh tambahan terapi obat}

Butuh tambahan terapi obat didefinisikan sebagai suatu kondisi klinis dan hasil pemeriksaan laboratorium yang menunjukkan bahwa pasien membutuhkan tambahan terapi obat untuk memperbaiki kondisinya, namun pasien belum mendapatkan terapi tersebut selama pasien menjalani rawat inap. Termasuk dalam 
Tabel III. Drug Related Problems Obat Antidiabetika Pada Pasien Rawat Inap DM Tipe 2 dengan Nyeri Neuropati

\begin{tabular}{lccc}
\hline Kategori DRPs & Jumlah Kejadian & Jumlah Pasien & Persentase (\%) \\
\hline Butuh tambahan terapi obat & 10 & 10 & 26,3 \\
Obat salah & 21 & 21 & 55,2 \\
Dosis terlalu rendah & 7 & 7 & 18,4 \\
Total & $\mathbf{3 8}$ & $\mathbf{3 8}$ & $\mathbf{1 0 0}$ \\
\hline
\end{tabular}

Tabel IV. Kondisi yang Membutuhkan Terapi Tambahan Obat

\begin{tabular}{|c|c|c|c|}
\hline Pasien & Obat yang Diterima & $\begin{array}{c}\text { Obat yang } \\
\text { Dibutuhkan }\end{array}$ & Kadar Glukosa Pada Pemeriksaan Akhir \\
\hline 1 & $\begin{array}{l}\text { Pioglitazone } \\
1 \times 15 \mathrm{mg}\end{array}$ & insulin basal & $\begin{array}{l}\text { GDS } 235 \mathrm{mg} / \mathrm{dL}, \text { GDP } 198 \mathrm{mg} / \mathrm{dL}, \text { GD2JPP } \\
216 \mathrm{mg} / \mathrm{dL}\end{array}$ \\
\hline 7 & Lantus $1 \times 20$ unit & Insulin rapid & GDS 249 mg/dL, GDP 203 mg/dL \\
\hline 14 & Novorapid 3x19 unit & Insulin basal & GDS 162 mg/dL, GDP 225, GD2JPP 296 \\
\hline 15 & $\begin{array}{l}\text { Pioglitazone } 1 \times 15 \mathrm{mg} \text {, } \\
\text { metformin } 3 \times 500 \mathrm{mg}\end{array}$ & insulin basal & $\begin{array}{l}\text { GDS } 259 \mathrm{mg} / \mathrm{dL} \text {, GDP } 225 \mathrm{mg} / \mathrm{dL}, \text { GD2JPP } \\
270 \mathrm{mg} / \mathrm{dL}\end{array}$ \\
\hline 21 & Pioglitazone $1 \times 15 \mathrm{mg}$ & insulin basal & $\begin{array}{l}\text { GDS } 198 \mathrm{mg} / \mathrm{dL}, \text { GDP } 221 \mathrm{mg} / \mathrm{dL}, \mathrm{GD} 2 J P P \\
216 \mathrm{mg} / \mathrm{dL}\end{array}$ \\
\hline 23 & Novorapid $3 \times 19$ unit & Insulin basal & $\begin{array}{l}\text { GDS } 162 \mathrm{mg} / \mathrm{dL}, \text { GDP } 211 \mathrm{mg} / \mathrm{dL}, \text { GD2JPP } \\
314 \mathrm{mg} / \mathrm{dL}\end{array}$ \\
\hline 29 & Lantus $1 \times 20$ unit & Insulin rapid & $\begin{array}{l}\text { GDS } 362 \mathrm{mg} / \mathrm{dL}, \text { GDP } 362 \mathrm{mg} / \mathrm{dL}, \mathrm{GD} 2 J P P \\
160 \mathrm{mg} / \mathrm{dL}\end{array}$ \\
\hline 30 & Lantus $1 \times 32$ unit & Insulin rapid & GDS 203 mg/dL, GDP 203 mg/dl \\
\hline 34 & $\begin{array}{l}\text { Novorapid } 3 \times 12 \text { unit, } \\
\text { metformin } 3 \times 500 \mathrm{mg}\end{array}$ & Insulin basal & $\begin{array}{l}\text { GDS } 464 \mathrm{mg} / \mathrm{dL}, \text { GDP } 261 \mathrm{mg} / \mathrm{dL}, \mathrm{GD} 2 J P P \\
268 \mathrm{mg} / \mathrm{dL}\end{array}$ \\
\hline 39 & Lantus $1 \times 20$ unit & Insulin rapid & $\begin{array}{l}\text { GDS } 490 \mathrm{mg} / \mathrm{dL}, \text { GDP } 209 \mathrm{mg} / \mathrm{dL}, \text { GD2JPP } \\
218 \mathrm{mg} / \mathrm{dL}\end{array}$ \\
\hline
\end{tabular}

kategori ini adalah diperlukannya kombinasi obat antidiabetik untuk mengatasi kadar gula darah pasien yang masih belum mencapai target terapi.

Penyebab terjadinya DRPS kategori butuh tambahan terapi obat pada 10 pasien ini adalah kondisi hiperglikemia yang masih dialami pasien selama dirawat inap meski sudah diberikan obat antidiabetika. Obat antidiabetika yang sudah diberikan ke pasien dinilai belum dapat mengendalikan kadar glukosa baik puasa, sewaktu maupun dua jam setelah makan sehingga perlu diberikan kombinasi untuk meningkatkan efek sinergisme obat antidiabetika.

Penambahan terapi insulin direkomendasikan oleh American Diabetes Association (2019) pada pasien diabetes melitus tipe 2 yang mengalami hiperglikemia pada perawatan rawat inap. Pada pasien no 1 , 15, dan 21 terlihat kadar glukosa darah sewaktu, puasa, dan 2 jam post prandial masih pada rentang diatas $180-200 \mathrm{mg} / \mathrm{dL}$. Pada kasus ini kendali glukosa prandial maupun post prandial belum tercapai. Kombinasi antara obat antidiabetika oral dan insulin diindikasikan bila terapi tunggal antidiabetika oral atau kombinasi antidiabetika oral belum dapat mencapai target glikemi 29.

Pioglitazone merupakan obat golongan thiazolidinedion dan bekerja dengan cara meningkatkan sensitivitas insulin dalam jaringan otot, hati, dan lemak serta memiliki efek dalam mengurangi produksi glukosa hepatik 16, 31. Pioglitazone dapat mengurangi A1C sebesar $1,5 \%$ dan gula darah puasa 
Anggraini Citra Ryshang Bathari, et al

Tabel V. Profil Pemeriksaan Gula Darah Pasien yang Menerima Terapi Insulin Basal

\begin{tabular}{ccccccc}
\hline \multirow{2}{*}{ Pasien } & \multicolumn{2}{c}{ GDS } & \multicolumn{3}{c}{ GDP } & \multicolumn{2}{c}{ GD2JPP } \\
\cline { 2 - 7 } & Pre & Post & Pre & Post & Pre & Post \\
\hline 7 & 348 & 249 & 207 & 203 & 287 & \\
29 & 509 & 362 & 246 & 362 & 242 & 160 \\
30 & 348 & 203 & 207 & 203 & 287 & \\
39 & 795 & 490 & 334 & 209 & 329 & 218 \\
\hline
\end{tabular}

sebesar 60 - 70 mg/dL ${ }^{30}$. Pasien nomor 1 telah mendapatkan pioglitazone $15 \mathrm{mg}$, namun glukosa post prandial pasien $216 \mathrm{mg} / \mathrm{dL}$ dan belum terkendali sampai pasien pulang. Demikian pula dengan glukosa prandial masih tinggi yaitu $198 \mathrm{mg} / \mathrm{dL}$. Kondisi ini menyebabkan sasaran glikemik pasien tidak tercapai sehingga membutuhkan terapi obat tambahan untuk dapat mengatasi tingginya kadar glukosa prandial maupun post prandial pasien. Hal serupa juga dialami pada pasien nomor 15 dan 21 dimana kadar glukosa post prandial masih diatas $200 \mathrm{mg} / \mathrm{dL}$ dan glukosa prandial masing-masing sebesar $225 \mathrm{mg} / \mathrm{dL}$ dan $221 \mathrm{mg} / \mathrm{dL}$. Disarankan insulin basal untuk mengatasi tingginya glukosa prandial. Penggunaan insulin rapid atau short acting diindikasikan pada pasien yang membutuhkan koreksi hiperglikemia ${ }^{12}$. Regimen insulin basal dan prandial juga merupakan terapi yang dipilih pada pasien non krtitikal dengan intake nutrisi yang baik 29. Penggunaan tunggal sliding scale insulin dalam jangka waktu yang lama pada pasien rawat inap sangat tidak dianjurkan ${ }^{17}$. Kombinasi insulin dan pioglitazone menurunkan $\mathrm{HbA} 1 \mathrm{C}$ sebesar 0,6 - 2,1\% ${ }^{18}$. Terapi kombinasi ini terbukti memberikan manfaat pada pasien diabetes di Jepang. Kombinasi pioglitazone dan insulin juga meningkatkan efek dalam kendali glukosa ${ }^{19}$. Kombinasi antara pioglitazone dan insulin dapat meningkatkan efek samping retensi cairan dan gagal jantung kongesti, sehingga penggunaannya harus hati-hati dan dihindari pada pasien dengan resiko penyakit gagal jantung ${ }^{20}$.

Kondisi yang memerlukan tambahan terapi obat berikutnya adalah pasien nomor 7 , 29, 30, dan 39. Keempat pasien telah menerima insulin basal (Lantus), namun gula darah sewaktu, prandial, maupun post prandial belum mencapai target walaupun terlihat kecenderungan penurunan gula darah (Tabel V).

Pada Tabel V dapat dilihat terdapat kecenderungan penurunan kadar glukosa darah pada keempat pasien yang menggunakan terapi insulin basal. Hanya pasien nomor 29 yang menunjukkan kenaikan GDP post pemberian insulin basal walaupun terdapat perbaikan yang cukup signifikan pada GDS dan GD2JPP. Insulin basal merupakan regimen insulin yang paling nyaman yang digunakan dan penggunaannya dapat ditambahkan bersama metformin atau obat antidiabetika oral yang lain. Dosis awal insulin basal dapat ditetapkan berdasarkan berat badan atau dimulai dari 10 unit per hari atau 0,1 - 0,2 unit/kg/hari dan berdasarkan derajat hiperglikemia pasien dengan titrasi dosis secara individual selama beberapa hari sampai dengan beberapa minggu selama masih diperlukan. Prinsip kerja insulin basal adalah mencegah produksi glukosa hepatik yang bertujuan untuk mempertahankan kondisi euglycemia semalaman dan diantara waktu makan ${ }^{21,22}$.

Intensifikasi pengobatan insulin bisa dilakukan dengan menambahkan dosis prandial ke insulin basal ${ }^{23}$. Pengendalian glukosa prandial dapat dimulai dengan memberikan dosis insulin prandial 50\% dari TDD (total daily dose) yang dibagi dalam tiga dosis dan diberikan sebelum makan ${ }^{24}$. Pada kasus pasien nomor 7, 29, 30, dan 39 disarankan untuk menambahkan insulin rapid sebelum makan untuk mencapai target glikemi. 
Tabel VI. Profil Pemeriksaan Gula Darah Pasien yang Menerima Terapi Insulin Rapid

\begin{tabular}{ccccccc}
\hline \multirow{2}{*}{ Pasien } & \multicolumn{2}{c}{ GDS } & \multicolumn{2}{c}{ GDP } & \multicolumn{2}{c}{ GD2JPP } \\
\cline { 2 - 7 } & Pre & Post & Pre & Post & Pre & Post \\
\hline 14 & 502 & 162 & 149 & 211 & 260 & 296 \\
23 & 502 & 162 & 149 & 211 & 564 & 314 \\
34 & 624 & 464 & 179 & 261 & 347 & 268 \\
\hline
\end{tabular}

Tabel VII. Identifikasi Drug Related Problems Kategori Dosis Terlalu Rendah

\begin{tabular}{clcccccc}
\hline \multirow{2}{*}{ Pasien } & \multirow{2}{*}{ Nama Obat dan Dosis } & \multicolumn{2}{c}{ GDS } & \multicolumn{2}{c}{ GDP } & \multicolumn{2}{c}{ GD2JPP } \\
\cline { 3 - 7 } & & Pre & Post & Pre & Post & Pre & Post \\
\hline 5 & Novomix 3 x 12 unit & 349 & 294 & 328 & 187 & & \\
13 & Novomix 3 x 16 unit & 384 & 405 & 168 & 322 & 423 & 294 \\
17 & Humalog mix 3 x 4 unit & 462 & 210 & 148 & 177 & 220 & 139 \\
35 & Humalog mix 3 x 4 unit & 196 & 267 & 171 & 280 & 341 & 342 \\
37 & Lantus 1 x 10 unit & 246 & 249 & 436 & 195 & 199 & 215 \\
39 & Lantus 1 x 20 unit & 795 & 490 & 334 & 209 & 329 & 218 \\
48 & Novomix 3 x 18 unit & 294 & 179 & 179 & 322 & 220 & 294 \\
\hline
\end{tabular}

Berdasarkan tabel VI terlihat bahwa nilai glukosa prandial maupun post prandial pasien masih belum dapat mencapai target glikemi. Nilai pemeriksaan kadar glukosa masih diatas $200 \mathrm{mg} / \mathrm{dL}$, sehingga diperlukan tambahan terapi insulin basal (dapat dimulai dari dosis 10 unit per hari) untuk mencapai target glikemi. Penambahan insulin basal diharapkan dapat memperbaiki kadar glukosa puasa, sehingga ketika kadar gula prandial turun maka kadar gula darah post prandial akan turun.

\section{Obat Salah}

DRPs kategori obat salah diidentifikasi selama pasien menjalani rawat inap. Kategori $D R P s$ obat salah adalah obat yang diberikan untuk pasien merupakan obat yang efektif tetapi bukan yang paling aman. Kategori $D R P s$ obat salah merupakan DRPs potensial yang terjadi pada 20 pasien yang mendapatkan terapi metformin untuk mengendalikan glukosa darah pasien baik dalam bentuk kombinasi bersama obat antidiabetika oral maupun injeksi.

Defisiensi vitamin B12 merupakan efek samping dari penggunaan metformin dan berhubungan dengan manifestasi neurologis dan neurokognitif termasuk didalamnya adalah neuropati peripheral dan otonom, degenerative tulang belakang subakut, delirium, dimensia, dan demyelinasi axonal. Penelitian randomized trial terbaru mengkonfirmasi bahwa penggunaan metformin menyebabkan defisiensi vitamin B12 dan dapat memperburuk symptom neuropati.

\section{Dosis Terlalu Rendah}

Luaran terapi yang tidak tercapai dapat terjadi apabila dosis terapi tidak adekuat atau rendah ${ }^{25}$. Terdapat tujuh kejadian DRP dosis terlalu rendah teridientifikasi pada penelitian ini. Dari tujuh pasien, lima diantaranya telah mendapatkan terapi insulin premixed namun belum dapat mencapai target kendali glikemik yang diinginkan. Identifikasi kejadian drug related problems kategori dosis terlalu rendah tersaji pada tabel VII.

Tabel VII menunjukkan sasaran kendali glikemik pasien DM tipe 2 dengan komplikasi nyeri neuropati belum tercapai meski sudah menggunakan insulin premix. Pada beberapa pasien $(5,17)$ terlihat kecenderungan penurunan gula darah sewaktu, prandial, dan post prandial meski belum mencapai target 
Tabel VIII. Jumlah Pasien Diabetes Tipe 2 dengan Komplikasi Nyeri Neuropati dengan Ketercapaian Target Glukosa Darah Saat Keluar dari Rumah Sakit Akademik UGM

\begin{tabular}{lcc}
\hline Kadar Gula Darah Pasien Saat Keluar RS & Jumlah Pasien & Persentase \\
\hline $\begin{array}{l}\text { GDS mencapai target }(<200 \mathrm{mg} / \mathrm{dL}) \text { dan atau GDP } \\
\text { mencapai target }(<130 \mathrm{mg} / \mathrm{dL})\end{array}$ & 28 & 56 \\
GDS dan atau GDP tidak mencapai target & 22 & 44 \\
\hline
\end{tabular}

Tabel IX. Rata-Rata Gula Darah Sewaktu (GDS) dan Gula Darah Puasa (GDP) Saat Masuk RS Pada Kelompok DRPs dan Non DRPs

\begin{tabular}{lcc}
\hline \multirow{2}{*}{$\begin{array}{l}\text { Jenis pemeriksaan gula darah pasien pada } \\
\text { saat masuk rumah sakit }\end{array}$} & \multicolumn{2}{c}{ Rata-rata kadar gula darah (mg/dL) } \\
\cline { 2 - 3 } & $\begin{array}{c}\text { Kelompok DRPs } \\
\mathbf{( N = 3 6 )}\end{array}$ & $\begin{array}{c}\text { Kelompok Non } \\
\text { DRPs (N=14) }\end{array}$ \\
\hline Gula Darah Sewaktu (GDS) & 352 & 204 \\
Gula Darah Puasa (GDP) & 212 & 155 \\
\hline
\end{tabular}

yang dikehendaki. Pada pasien yang lain terlihat kadar glukosa masih fluktuatif dan belum mencapai target glikemik.

Intensifikasi terapi insulin dapat direkomendasikan pada pasien DM tipe 2 yang menggunakan insulin bila nilai $\mathrm{HbA1C}$ lebih dari $7 \%$ dan kadar gula darah puasa lebih dari $110 \mathrm{mg} / \mathrm{dL}{ }^{13}$. Penyesuaian dosis yang disarankan pada pasien dengan gula darah puasa lebih dari $178 \mathrm{mg} / \mathrm{dL}$ adalah menaikkan dosis insulin premixed sebanyak 4 unit dari dosis awal (pasien nomor 5,13, 17, 35, dan 48) 13. Pasien nomor 37 dan 39 mendapatkan insulin basal masing-masing $1 \mathrm{x}$ 10 unit dan $1 \times 20$ unit. Pada pasien nomor 37 kadar gula darah puasa sebesar $195 \mathrm{mg} / \mathrm{dL}$ sehingga belum mencapai target glikemik. Disarankan untuk menaikkan dosis insulin basal sebanyak 4 unit sehingga dosis menjadi $1 \times 14$ unit. Untuk pasien nomor 39 kadar glukosa puasa sebesar $329 \mathrm{mg} / \mathrm{dL}$ juga disarankan untuk menaikkan dosis insulin basal sebanyak 4 unit sehingga dosis insulin basal menjadi $1 \times 24$ unit. Monitoring kejadian hipoglikemia tetap harus dilakukan, dan bila terjadi maka dosis insulin diturunkan.

\section{Luaran Terapi Ketercapaian Target Glukosa Darah Pasien Saat Keluar Rumah Sakit}

Pada penelitian ini parameter luaran terapi berupa pengukuran kadar A1C tidak digunakan karena pemeriksaan A1C tidak rutin dilakukan. Pemeriksaan kadar gula darah yang rutin dilakukan adalah glukosa darah puasa dan sewaktu. Pemeriksaan gula darah 2 jam setelah makan hanya diperiksa pada beberapa pasien. Hasil capaian kadar gula darah pada pasien setelah pemberian terapi antidiabetik dapat dipengaruhi oleh penggunaan kombinasi obat antidiabetik baik injeksi maupun oral serta dosis obat antidiabetik yang digunakan seperti yang telah dijelaskan secara detail pada pembahasan sebelumnya.

Tabel VIII menunjukkan bahwa ketercapaian sasaran glikemik pasien DM tipe 2 dengan komplikasi nyeri neuropati saat selesai menjalani rawat inap di Rumah Sakit Akademik UGM sebesar 56\%. Hal ini menunjukkan $56 \%$ pasien memiliki respon yang baik terhadap terapi obat antidiabetika meskipun pengukuran parameter keberhasilan terapi ditentukan dengan hanya salah satu parameter pemeriksaan gula darah. Sebanyak $44 \%$ pasien dalam penelitian ini tidak mencapai target kendali glikemik selain diakibatkan mengalami kejadian DRPs juga disebabkan oleh faktor usia, kompleksitas terapi, durasi diabetes 26,27 dan tingginya kadar glukosa darah saat pasien masuk ke rumah sakit. Tabel IX berikut menunjukkan rata-rata gula darah sewaktu (GDS) dan gula darah puasa (GDP) pada saat masuk rumah sakit. Terlihat pada kelompok $D R P s$ rata-rata 
Tabel X. Hubungan Drug Related Problems Obat Antidiabetika Terhadap Ketercapaian Target Glukosa Darah Pasien

\begin{tabular}{lcccc}
\hline \multirow{2}{*}{ DRPS } & \multicolumn{2}{c}{ Ketercapaian Target Glukosa Darah } & Total & $p$-value \\
\cline { 2 - 5 } & Tidak Tercapai & Tercapai & & \\
\hline Terjadi DRPs & 21 & 15 & 36 & 0,005 \\
Tidak terjadi DRPs & 2 & 12 & 14 & \\
\hline
\end{tabular}

gula darahnya lebih tinggi dari kelompok non DRPs.

Pasien dapat diijinkan pulang dengan kadar gula darah yang masih belum mencapai target dan diputuskan untuk menjalani perawatan rawat jalan karena terdapat pertimbangan klinis lain yang ditetapkan oleh dokter penanggung jawab pasien yang terkait dengan perkembangan dan kestabilan pasien serta membaiknya gejala yang dirasakan pasien saat masuk rumah sakit. Kecenderungan penurunan kadar gula darah pasien juga menjadi pertimbangan untuk mengizinkan pasien pulang dan melakukan edukasi kepada pasien untuk melakukan perawatan rawat jalan.

\section{Hubungan Drug Related Problems Terhadap Ketercapaian Kendali Glikemik} Analisis hubungan antara kejadian $D R P S$ terhadap ketercapaian target kadar glukosa darah pasien menggunakan uji Chisquare test menunjukkan adanya hubungan antara kejadian DRPs terhadap ketercapaian target glukosa darah pasien $(p<0,05)$.

Tabel X menunjukkan kelompok pasien yang mengalami kejadian DRPS sebanyak 21 pasien tidak dapat mencapai target kendali glukosa darah. Hal ini disebabkan karena pasien masih membutuhkan terapi tambahan obat untuk meningkatkan efek sinergisme obat antidiabetika dan dosis antidiabetik tidak adekuat untuk menghasilkan efek penurunan glukosa. Sebanyak 15 pasien pada kelompok pasien yang mengalami kejadian $D R P S$ dapat mencapai target kendali glukosa darah. Kategori DRPs yang terjadi pada kelompok ini adalah obat salah dimana pasien mendapatkan metformin. Metformin merupakan first line antidiabetes oral berdasarkan American Diabetes Association 2019 yang efektif, aman, murah, serta dapat mengurangi resiko kejadian kardiovaskular dan kematian. DRPS yang terjadi pada kelompok ini merupakan $D R P$ s potensial yang mungkin terjadi terkait efek samping obat namun tidak terpengaruh pada efikasinya.

Pada kelompok pasien yang tidak mengalami kejadian DRPS hanya 2 pasien yang tidak dapat mencapai target kendali glikemik. Pada kelompok ini pasien telah mendapatkan obat yang sesuai dengan dosis yang adekuat dan terdapat kecenderungan penurunan glukosa darah yang signifikan dengan GD2JPP pasien $<140 \mathrm{mg} / \mathrm{dL}$. Sebanyak 12 pasien pada kelompok yang tidak mengalami kejadian DRPS dapat mencapai target kendali glikemik.

Keterbatasan penelitian dengan pengambilan data secara retrospektif dari rekam medis menyebabkan banyak data yang tidak tertulis dengan lengkap sehingga menyebabkan keterbatasan jumlah sampel yang memenuhi kriteria inklusi maupun keterbatasan dalam analisis luaran terapi.

\section{KESIMPULAN}

Hasil penelitian menunjukkan 38 kejadian drug related problems teridentifikasi pada 36 pasien $(72 \%)$ pasien DM tipe 2 dengan komplikasi nyeri neuropati. Sejumlah $54 \%$ pasien mencapai target kendali glikemik berdasarkan kriteria American Diabetes Association 2019. Kejadian drug related problems berhubungan dengan ketercapaian kendali glikemik pada pasien diabetes melitus tipe 2 dengan komplikasi nyeri neuropati rawat inap $(\mathrm{p}<0,05)$. Apoteker harus mampu melakukan identifikasi terhadap kejadian DRPs yang merupakan bagian dari pharmaceutical care yang bertujuan untuk meningkatkan keberhasilan terapi pasien. 
DAFTAR PUSTAKA

1. Juster-Switlyk K, Smith AG. Updates in diabetic peripheral neuropathy. F1000Research. 2016;5(0):1-7.

2. Cho, N. H., Shaw, J. E., Karuranga, S., et al. IDF Diabetes Atlas: Global estimates of diabetes prevalence for 2017 and projections for 2045. Diabetes Research and Clinical Practice. 2018; 138: 271-281.

3. Dinas Kesehatan DIY. Provinsi Di Yogyakarta Tahun 2017. Profil Kesehat Provinsi Yogyakarta. 2017;38-9.

4. Pop-busui R, Boulton AJM, Feldman EL, et al. Diabetic Neuropathy: A Position Statement by the American Diabetes Association. 2017;40 (January):136-154.

5. Ismail-Beigi F, Craven T, Banerii MA, et al. Effect of intensive treatment of hyperglycaemia on microvascular outcomes in type 2 diabetes: An analysis of the ACCORD randomised trial. Lancet. 2010;376(9739):419-430.

6. Fowler MJ. Diabetes Foundation: Microvascular and Macrovascular Complications of Diabetes. Clin Diab. 2008;26(3):77-82.

7. Pharmaceutical care network Europe foundation. Classification for Drug related problems V 8.01. PCNE Classif. Published online 2017:1-10. https://www.pcne.org/upload/files/215 _PCNE_classification_V8-01.pdf

8. Huri HZ, Ling LC. Drug-related problems in type 2 diabetes mellitus patients with dyslipidemia. Published online 2013.

9. Zaman Huri H, Fun Wee H. Drug related problems in type 2 diabetes patients with hypertension: A crosssectional retrospective study. $B M C$ Endocr Disord. Published online 2013. doi:10.1186/1472-6823-13-2

10. Hartuti S, Nasution A, Syafril S. The Effect of Drug-Related Problems on Blood Glucose Level in the Treatment of Patients with Type 2 Diabetes Mellitus. Open Access Maced J Med Sci. 2019 Jun 15; 7(11):1798- 1802.
11. PERKENI. Indonesia, P. E. (2015). Pengelolaan Dan Pencegahan Diabetes Melitus Tipe $2 \mathrm{Di}$ Indonesia. PB. PERKENI.; 2015.

12. Moghissi ES, Korytkowski MT, DiNardo M, et al. American Association of Clinical Endocrinologists and American Diabetes Association consensus statement on inpatient glycemic control. Diabetes Care. 2009;32(6):1119-1131.

13. Silver B, Ramaiya K, Andrew SB, et al. EADSG Guidelines: Insulin Therapy in Diabetes. Diabetes Ther. 2018;9(2):449492.

14. Dormandy JA, Charbonnel B, Eckland DJA, et al. Secondary prevention of macrovascular events in patients with type 2 diabetes in the PROactive Study (PROspective pioglitAzone Clinical Trial in macroVascular Events): A randomised controlled trial. Lancet. 2005;366(9493):1279-1289.

15. Moon MK, Hur KY, Ko S, et al. Combination therapy of oral hypoglycemic agents in patients with type 2 diabetes mellitus. Published online 2017:974-983.

16. Saltiel AR, Olefsky JM. Thiazolidinediones in the treatment of insulin resistance and type II diabetes. Diabetes. 1996;45(12):1661-1669.

17. Draznin B, Gilden J, Golden SH, et al. Pathways to quality inpatient management of hyperglycemia and diabetes: A call to action. Diabetes Care. 2013;36(7):1807-1814.

18. Strowig SM, Raskin P. Combination therapy using metformin or thiazolidinediones and insulin in the treatment of diabetes mellitus. Published online 2005:633-641.

19. Yamanouchi T, Press D. Concomitant therapy with pioglitazone and insulin for the treatment of type 2 diabetes. Published online 2010:189-197.

20. Berhanu P, Perez A, Yu S. Effect of pioglitazone in combination with insulin therapy on glycaemic control, 
insulin dose requirement and lipid profile in patients with type 2 diabetes previously poorly controlled with combination therapy. Published online 2007:512-520.

21. Porcellati F, Lucidi $\mathrm{P}$, Cioli $\mathrm{P}$, et al. Pharmacokinetics and pharmacodynamics of insulin glargine given in the evening as compared with in the morning in type 2 diabetes. Diabetes Care. 2015;38(3):503-512.

22. Wang Z, Hedrington MS, Joy NG, et al. Dose-response effects of insulin glargine in type 2 diabetes. Diabetes Care. 2010;33(7):1555-1560.

23. Rodbard HW, Visco VE, Andersen $\mathrm{H}$, et al. Treatment intensification with stepwise addition of prandial insulin aspart boluses compared with full basal-bolus therapy (FullSTEP Study): A randomised, treat-to-target clinical trial. Lancet Diabetes Endocrinol. 2014;2(1):30-37.

24. Handelsman $\mathrm{Y}$, Bloomgarden $\mathrm{ZT}$, Grunberger G, et al. American Association of Clinical Endocrinologists and American College of Endocrinology - Clinical practice guidelines for developing a diabetes mellitus comprehensive care plan -
2015. Endocr Pract. 2015;21(4):1-87.

25. Cipolle RJ, Strand LM, Morley PC. Pharmaceutical Care Practice:; 2012.

26. Yigazu DM, Desse TA. Glycemic control and associated factors among type 2 diabetic patients at Shanan Gibe Hospital, Southwest Ethiopia. BMC Res Notes. 2017;10(1):1-6.

27. Juarez DT, Sentell T, Tokumaru S, et al. Factors Associated With Poor Glycemic Control or Wide Glycemic Variability Among Diabetes Patients in Hawaii, 2006 - 2009. 2012;9:1-10.

28. Bc C, Aa L, El F, et al. Enhanced glucose control for preventing and treating diabetic neuropathy (Review). 2012;(6).

29. American Diabetes Association. Diabetes care. Standars of Medical Care in Diabetes:; 2019

30. Wells BG, DiPiro CV, DiPiro JT, et al. Endocrinologic Disorder: Diabetes Mellitus. Pharmacotherapy Handbook $9^{\text {th }}$ Edition." McGraw-Hill Education. 2014; (19):161-175.

31. Inzucchi SE, Maggs DG, Spollett GR, et al. Efficacy and Metabolic Effects of Metformin and Troglitazone in Type II Diabetes Mellitus. New England Journal of Medicine. 1998; 338 (13): 867-873. 